University of Nebraska - Lincoln

DigitalCommons@University of Nebraska - Lincoln

January 1991

\title{
Effects of breed group by location interaction on crossbred cattle in Nebraska and Florida
}

\author{
T. A. Olson \\ University of Florida \\ K. Euclides Filho \\ University of Florida \\ L. V. Cundiff \\ US Meat Animal Research Center, USDA-ARS, Clay Center, NE \\ M. Koger \\ University of Florida \\ W. T. Butts Jr. \\ USDA-ARS
}

See next page for additional authors

Follow this and additional works at: https://digitalcommons.unl.edu/usdaarsfacpub

Part of the Agricultural Science Commons

Olson, T. A.; Filho, K. Euclides; Cundiff, L. V.; Koger, M.; Butts, W. T. Jr.; and Gregory, K. E., "Effects of breed group by location interaction on crossbred cattle in Nebraska and Florida" (1991). Publications from USDA-ARS / UNL Faculty. 157.

https://digitalcommons.unl.edu/usdaarsfacpub/157

This Article is brought to you for free and open access by the U.S. Department of Agriculture: Agricultural Research Service, Lincoln, Nebraska at DigitalCommons@University of Nebraska - Lincoln. It has been accepted for inclusion in Publications from USDA-ARS / UNL Faculty by an authorized administrator of DigitalCommons@University of Nebraska - Lincoln. 


\section{Authors}

T. A. Olson, K. Euclides Filho, L. V. Cundiff, M. Koger, W. T. Butts Jr., and K. E. Gregory 


\title{
Effects of breed group by location interaction on crossbred cattle in Nebraska and Florida
}

\author{
T. A. Olson, ${ }^{2}$ \\ K. Euclides Filho, ${ }^{2}$ \\ L. V. Cundiff, ${ }^{3}$ M. Koger, ${ }^{2}$ \\ W. T. Butts $\mathrm{Jr},{ }^{1}$ and \\ K. E. Gregory ${ }^{3}$ \\ 1 Subtropical Agricultural Research Station, USDA-ARS, Brooksville, FL \\ 2 Animal Science Dept., Univ. of Florida, Gainesville \\ 3 US Meat Animal Research Center, USDA-ARS, Clay Center, NE.
}

Data on 2,744 calves produced in Clay Center, Nebraska, and Brooksville, Florida, were used to evaluate the importance of genotype $\times$ location interactions on the reproductive and maternal performance of eight breed groups of F1 crossbred cows. A total of $648 \mathrm{~F} 1$ crossbred cows included Bos taurus $\times$ Bos taurus (Bt $\times \mathrm{Bt}$ ) crosses: Hereford $\times$ Angus reciprocal crossbreds $(\mathrm{HA}$ and $\mathrm{AH})$, Pinzgauer $\times$ Angus $(\mathrm{PA})$, Pinzgauer $\times$ Hereford $(\mathrm{PH})$; and Bos indicus $\times$ Bos taurus $(\mathrm{Bi} \times \mathrm{Bt})$ crosses: Brahman $\times$ Angus $(\mathrm{BA})$, Brahman $\times$ Hereford $(\mathrm{BH})$, Sahiwal $\times$ Angus $(\mathrm{SA})$ and Sahiwal $\times$ Hereford $(\mathrm{SH})$. The first calf crop was sired by Red Poll bulls. All remaining calf crops were sired by Simmental bulls. Although the pregnancy rate was $9 \%$ higher in Nebraska, the rate of unassisted calvings and calf survival rate were both $4.6 \%$ lower in Nebraska. Calf birth and weaning weights were 8.0 and $15.6 \mathrm{~kg}$ heavier in Nebraska than in Florida. $\mathrm{Bi} \times \mathrm{Bt}$ dams exceeded ( $\mathrm{P}$ less than .001) Bt $\times \mathrm{Bt}$ crossbred dams for all traits except age of calf at weaning and calfsurvival rates (P greater than .10). Birth weights of calves from $\mathrm{Bi} \times \mathrm{Bt}$ crossbred dams were $3.4 \mathrm{~kg}$ lighter than those from the $\mathrm{Bt} \times \mathrm{Bt}$ crossbred dams. The interaction of location with the breed group comparison of $\mathrm{Bi} \times \mathrm{Bt} \mathrm{vs} \mathrm{Bt} \times \mathrm{Bt}$ crossbred dams was significant for pregnancy rate, calf age at weaning, rate of unassisted calving and all weight traits. Adjusted weaning weights of calves from HA, AH, PA, PH, BA, BH, SA and SH cows were as follows: HA, 194 and 222; AH, 202 and 230; PA, 213 and 242; PH, 217 and 245; BA, 251 and 254; BH, 252 and 254; SA, 236 and 238; and SH, 238 and $243 \mathrm{~kg}$, respectively, in Florida and Nebraska. Bos indicus-sired cows (BA, BH, SA and $\mathrm{SH}$ ) weaned essentially equal-weight calves at both locations, whereas calves from $\mathrm{Bt} \times \mathrm{Bt}$ crossbred cows (HA, AH, PA, PH) were about $28 \mathrm{~kg}$ lighter in Florida. 


\title{
EFFECTS OF BREED GROUP BY LOCATION INTERACTION ON CROSSBRED CATTLE IN NEBRASKA AND FLORIDA ${ }^{1}$
}

\author{
T. A. Olson ${ }^{2}$, K. Euclides Filho ${ }^{2}$, L. V. Cundiff ${ }^{3}$, \\ M. Koger ${ }^{2}$, W. T. Butts, Jr. ${ }^{4}$ and K. E. Gregory ${ }^{3}$ \\ Subtropical Agricultural Research Station, \\ USDA-ARS; University of Florida, Brooksville 33512; \\ and U.S. Department of Agriculture, Clay Center, NE 68933
}

\begin{abstract}
Data on 2,744 calves produced in Clay Center, Nebraska and Brooksville, Florida were used to evaluate the importance of genotype $\times$ location interactions on the reproductive and maternal performance of eight breed groups of $F_{1}$ crossbred cows. A total of $648 F_{1}$ crossbred cows included Bos taurus $\times$ Bos taurus $(\mathrm{Bt} \times \mathrm{Bt})$ crosses: Hereford $\times$ Angus reciprocal crossbreds (HA and AH), Pinzgauer $\times$ Angus (PA), Pinzgauer $\times$ Hereford (PH); and Bos indicus $\times$ Bos taurus $(\mathrm{Bi} \times \mathrm{Bt}$ ) crosses: Brahman $\times$ Angus $(\mathrm{BA})$, Brahman $\times$ Hereford (BH), Sahiwal $\times$ Angus (SA) and Sahiwal $\times$ Hereford (SH). The first calf crop was sired by Red Poll bulls. All remaining calf crops were sired by Simmental bulls. Although the pregnancy rate was $9 \%$ higher in Nebraska, the rate of unassisted calvings and calf survival rate were both $4.6 \%$ lower in Nebraska. Calf birth and weaning weights were 8.0 and $15.6 \mathrm{~kg}$ heavier in Nebraska than in Florida. Bi $\times \mathrm{Bt}$ dams exceeded $(P<$ $.001) \mathrm{Bt} \times \mathrm{Bt}$ crossbred dams for all traits except age of calf at weaning and calf-survival rates $(P>.10)$. Birth weights of calves from $\mathrm{Bi} \times \mathrm{Bt}$ crossbred dams were $3.4 \mathrm{~kg}$ lighter than those from the $\mathrm{Bt} \times \mathrm{Bt}$ crossbred dams. The interaction of location with the breed group comparison of $\mathrm{Bi} \times \mathrm{Bt}$ vs $\mathrm{Bt} \times \mathrm{Bt}$ crossbred dams was significant for pregnancy rate, calf age at weaning, rate of unassisted calving and all weight traits. Adjusted weaning weights of calves from HA, AH, PA, PH, BA, BH, SA and SH cows were as follows: HA, 194 and 222; AH, 202 and 230; PA, 213 and 242; PH, 217 and 245; BA, 251 and 254; BH, 252 and 254; SA, 236 and 238; and SH, 238 and $243 \mathrm{~kg}$, respectively, in Florida and Nebraska. Bos indicus-sired cows (BA, BH, SA and SH) weaned essentially equal-weight calves at both locations, whereas calves from $\mathrm{Bt} \times \mathrm{Bt}$ crossbred cows (HA, AH, PA, PH) were about $28 \mathrm{~kg}$ lighter in Florida.

Key Words: Genotype Environment Interaction, Zebu, Bos taurus, Reproduction, Matemal Effects, Cattle
\end{abstract}

J. Anim. Sci. 1991. 69:104-114

\section{Introductlon}

The importance of genotype $\times$ location (Florida and Montana) interactions on repro-

\footnotetext{
${ }^{1}$ Florida Agric. Exp. Sta. Journal Series No. R-00122.

${ }^{2}$ Anim. Sci. Dept., Univ. of Florida, Gainesville 32611.

${ }^{3}$ U.S. Meat Anim. Res. Center, USDA-ARS, Clay Center.

${ }^{4}$ Subtropical Agric. Res. Sta., USDA-ARS, Brooksville.

Received October 20, 1989.

Accepted July 17, 1990.
}

ductive and weight traits of beef cattle is well documented in purebred Hereford cattle (Butts et al., 1971; Bums et al., 1979; Koger et al., 1979; Pahnish et al., 1983, 1985). In these studies the lines that performed best for weight traits were those selected at the location in which they were performing. Koger et al. (1975) demonstrated that Brahman, Shorthorn and Brahman $\times$ Shorthom $F_{1}$ crossbred cows differed in their responses to improved forage quality and quantity in Florida. Brahman $\times$ Bos taurus $F_{1}$ crossbred cows have performed well under subtropical conditions (Koger et al., 
1975; Peacock et al., 1981). However, the need to investigate the performance of Zebu $\times B o s$ taurus crossbreds under a broader range of environments, as discussed by Gregory and Cundiff (1980), led to the development of the present study. This study reports the pregnancy rates of Brahman $x$ Angus, Brahman $\times$ Hereford, Sahiwal $x$ Angus, Sahiwal $x$ Hereford, Pinzgauer $x$ Angus, Pinzgauer $\times$ Hereford, Hereford $x$ Angus and Angus $x$ Hereford $F_{1}$ crossbred cows and the survival rate and birth and weaning traits of their progeny. The Sahiwal is a Bos indicus breed that has been selected for and is considered higher in milk production than most other Zebu breeds. These cattle were part of Cycle III of the Germ Plasm Evaluation Program at the Roman L. Hruska U.S. Meat Animal Research Center. The objectives of this study were to evaluate the reproductive and matemal characteristics of Bos taurus $\times$ Bos taurus (Bt $\times \mathrm{Bt})$ and Bos indicus $\times$ Bos taurus $(\mathrm{Bi} \times \mathrm{Bt})$ $F_{1}$ cows under two environments (i.e., central Florida and Nebraska) and to assess the importance of genotype $\times$ location interaction effects on cow productivity.

\section{Material and Methods}

This study included weight and survival data on 2,744 crossbred calves produced from eight types of $F_{1}$ dams including HerefordAngus (HA), Angus-Hereford (AH), Pinzgauer-Angus (PA), Pinzgauer-Hereford (PH), Sahiwal-Angus (SA), Sahiwal-Hereford (SH), Brahman-Angus (BA) and Brahman-Hereford (BH). These dams were produced during 1975 and 1976 in Cycle III of the Germ Plasm Evaluation Program of the U.S. Meat Animal Research Center (MARC) at Clay Center, Nebraska. The cows were progeny of Hereford and Angus dams that had been artificially inseminated to Hereford, Angus, Pinzgauer, Sahiwal and Brahman sires. Semen was used from a total of 13 Hereford, 16 Angus, 17 Brahman, 6 Sahiwal and 9 Pinzgauer sires. Details regarding preweaning management and performance of the heifers up to weaning were reported by Gregory et al. (1979).

Shortly after weaning in November of each year, half of each group of patemal half-sib heifers was transferred to the Subtropical Agricultural Research Station at Brooksville, Florida; the other half remained at MARC. The number of cows in each breed group of dam at each location and the number of records for each category of traits analyzed are shown in Table 1. The heifers were maintained under standard management practices at each location. At MARC, the heifers from the 1975 calf crop were fed, for the first $41 \mathrm{~d}$ postweaning, a diet composed of $60 \%$ com silage, $36 \%$ rolled com and $4 \%$ soybean meal, plus antibiotics. The diet was changed after d 41 to one containing $80 \%$ corn silage, $14 \%$ rolled corn and $6 \%$ protein supplement (as-fed basis). This diet was fed for $27 \mathrm{~d}$. Heifers then were given ad libitum access for $110 \mathrm{~d}$ to a diet of $50 \%$ com silage, $20 \%$ sorghum silage and $30 \%$ alfalfa haylage. They were moved to an improved cool-season pasture in April 1976. The 1976 heifers, following weaning, were fed a diet of $60 \%$ com silage, $36 \%$ alfalfa haylage and $4 \%$ protein supplement (with antibiotics) for $57 \mathrm{~d}$. The heifers then were given ad libitum access to a diet of equal parts of corn silage and alfalfa haylage for $127 \mathrm{~d}$ after which they were moved to a cool-season pasture in April 1977.

At Brooksville, Florida, the transferred heifers were fed, from November to April of each year, a diet of a $20 \%$ protein range pellet, molasses and grass hay. The type of hay varied according to availability of forage, but it included Bahiagrass, Pangola and Coastal bermudagrass hays. Heifers were maintained on permanent grass pastures that consisted mainly of Pensacola Bahiagrass (Paspalum notatum, Flugge).

Females at both the Florida and Nebraska locations were pasture-mated in multisire herds to Red Poll bulls originating from the same population at MARC for their first calving and to upgraded (7/8) Simmental bulls originating from the same population at MARC for all subsequent calf crops. Heifers maintained at the Nebraska location were mated to calve at 2 yr of age. Due to the difference in breeding seasons between Nebraska and Florida, May 15 to July 20 for Clay Center and March 15 to May 20 for Brooksville, heifers born in Nebraska and transferred to Florida did not reach puberty early enough to calve as 2-yr-olds and were bred to calve first as they approached $3 \mathrm{yr}$ of age. There was no culling of females other than for sickness, extreme unsoundness, or for being open after two consecutive breeding seasons. The number of females eliminated was small and no relationship with breed group was observed. 
TABLE 1. NUMBER OF COWS AND OF PREGNANCY, BIRTH AND WEANING RECORDS BY BREED GROUP AND LOCATION

\begin{tabular}{|c|c|c|c|c|}
\hline \multirow[b]{2}{*}{ Breed group ${ }^{a}$} & \multirow[b]{2}{*}{$\begin{array}{l}\text { No. }{ }^{b} \\
\text { of cows }\end{array}$} & \multicolumn{3}{|c|}{ No. of records analyzed } \\
\hline & & $\begin{array}{l}\text { Pregnancy } \\
\text { rate }\end{array}$ & $\begin{array}{l}\text { Birth } \\
\text { traits }\end{array}$ & $\begin{array}{l}\text { Weaning } \mathrm{d} \\
\text { traits }\end{array}$ \\
\hline \multicolumn{5}{|l|}{ Florida } \\
\hline Hereford-Angus (HA) & 34 & 122 & 93 & 89 \\
\hline Angus-Hereford (AH) & 26 & 99 & 88 & 87 \\
\hline Pinzgauer-Angus (PA) & 35 & 132 & 107 & 99 \\
\hline Pinzgauer-Hereford (PH) & 26 & 96 & 72 & 67 \\
\hline Brahman-Angus (BA) & 35 & 134 & 113 & 111 \\
\hline Brahman-Hereford (BH) & 28 & 107 & 94 & 90 \\
\hline Sahiwal-Angus (SA) & 33 & 129 & 116 & 113 \\
\hline Sahiwal-Hereford (SH) & 30 & 115 & 102 & 99 \\
\hline \multicolumn{5}{|l|}{ Nebraska } \\
\hline Hereford-Angus & 70 & 385 & 351 & 320 \\
\hline Angus-Hereford & 31 & 173 & 155 & 146 \\
\hline Pinzgauer-Angus & 68 & 345 & 303 & 280 \\
\hline Pinzgauer-Hereford & 44 & 231 & 204 & 182 \\
\hline Brahman-Angus & 60 & 335 & 310 & 287 \\
\hline Brahman-Hereford & 42 & 234 & 212 & 191 \\
\hline Sahiwal-Angus & 54 & 286 & 270 & 249 \\
\hline Sahiwal-Hereford & 32 & 172 & 154 & 144 \\
\hline
\end{tabular}

asire breed listed first.

bincludes all females with at least one pregnancy record.

'Traits include birth weight, percentage of normal calving and percentage of survival.

${ }^{\mathrm{d}}$ Traits include weaning weight, preweaning average daily gain and age of calf at weaning.

The cows were maintained on improved pastures through November, beginning in midMarch in Florida and mid-April in Nebraska. Legume or grass hay and a protein supplement were fed during the winter months at both locations. Calves were born in March and April at the Nebraska location and from late December through February in Florida. Within 24 to $48 \mathrm{~h}$ after birth, all calves were identified and weighed and male calves were castrated. Subjective calving difficulty scores were assigned at both locations. Because a different scoring procedure was used at each location, all categories of assisted calving were combined and were recorded as 0 . A score of 1 was given to cows that calved unassisted. Cows were palpated for pregnancy at or shortly after weaning. The survival rate was coded as 1 for calves that survived to weaning; stillborn calves and calves that died before weaning were coded as a 0 . Calves were weaned in October at the Nebraska location and in August in Florida when they were approximately 201 and $218 \mathrm{~d}$ of age, respectively. Calf age at weaning also was analyzed as a reproductive trait because it was an indication of the length of time from the initiation of the breeding season until the time of conception. This trait also was influenced by gestation length and by calf survival; calves that did not survive did not have a calf age at weaning recorded.

Statistical Analyses. The traits analyzed were pregnancy rate, birth weight, rate of unassisted calving, weaning weight, survival rate to weaning, age at weaning, and preweaning growth rate. All traits were analyzed by method of least squares analysis of variance utilizing LSMLMW (Harvey, 1987). Because cows were nested within a breed group and location, a variable reflecting the interaction of location and breed group (LBG) was included as a fixed effect in the analyses of all traits. Other fixed effects in the statistical model were year, sex of calf and significant firstorder interactions. The linear effect of age of dam and its interaction with LBG were included in the analysis of rate of unassisted calving. The linear and quadratic effects of age of calf at weaning were included as covariates in the analysis of weaning weight and preweaning average daily gain. Cows nested within location-breed group of dam were random and were absorbed. The LSMLMW procedure also allowed the estimation of the repeatability of all traits evaluated. Linear 
TABLE 2. MEAN SQUARES AND LEVELS OF SIGNIFICANCE FROM COMBINED LEAST SQUARES ANALYSIS OF VARIANCE OF PREGNANCY, CALVING AND SURVIVAL TRAITS

\begin{tabular}{|c|c|c|c|c|c|c|c|c|c|}
\hline \multirow[b]{3}{*}{$\begin{array}{l}\text { Source of } \\
\text { Variation }\end{array}$} & \multicolumn{9}{|c|}{ Trait } \\
\hline & \multicolumn{3}{|c|}{ Pregnancy rate, \% } & \multicolumn{3}{|c|}{$\begin{array}{c}\text { Rate of } \\
\text { unassisted calving, \% }\end{array}$} & \multicolumn{3}{|c|}{ Survival rate, \% } \\
\hline & df & $\begin{array}{l}\text { Mean } \\
\text { square }\end{array}$ & $\begin{array}{l}\text { Level of } \\
\text { significance }\end{array}$ & df & $\begin{array}{l}\text { Mean } \\
\text { square }\end{array}$ & $\begin{array}{l}\text { Level of } \\
\text { significance }\end{array}$ & df & $\begin{array}{l}\text { Mean } \\
\text { square }\end{array}$ & $\begin{array}{l}\text { Level of } \\
\text { significance }\end{array}$ \\
\hline $\mathrm{LBG}^{\mathrm{a}}$ & 15 & .5036 & $.0000^{b}$ & 15 & .7468 & $.0000^{b}$ & 15 & .1154 & $.1396^{b}$ \\
\hline Cow:LBG & 636 & .1254 & .0000 & 609 & .0691 & .0014 & 609 & .0823 & .0000 \\
\hline Year & 5 & .2336 & .0023 & 5 & 1.6320 & .0000 & 5 & .0469 & .5425 \\
\hline $\operatorname{Sex}$ & & & & 1 & .4740 & .0040 & 1 & .5772 & .0016 \\
\hline $\mathbf{L B G} \times \mathbf{Y e a r}$ & 67 & .1208 & .0000 & & & & 67 & .0903 & .0026 \\
\hline LBG $\times$ Sex & & & & 15 & .1103 & .0167 & & & \\
\hline Age of dam(AD)-Linear & & & & 1 & .1987 & .0622 & & & \\
\hline LBG $\times$ AD-Linear & & & & 15 & .3052 & .0000 & & & \\
\hline Remainder & 2,371 & .0622 & & 2,082 & .0571 & & 2,046 & .0577 & \\
\hline
\end{tabular}

${ }^{a}$ The combined effect of location and breed group within location.

${ }^{b}$ The mean square for cow:LBG was used to test the significance of LBG.

functions of the LBG means were computed to evaluate effects of location and specific comparisons among breed groups of dams and their interactions with location. The coefficients for the contrast statements used to evaluate the effects of the interactions of location with specific breed group comparisons were derived by multiplying the coefficients for location with those of the specific breed group contrast. The breed group of dam linear functions and their interactions with locations of most interest were the comparisons of $\mathrm{Bi} \times$ $\mathrm{Bt}$ crossbred dams with the $\mathrm{Bt} \times \mathrm{Bt}$ crossbred dams (BGA), of crossbred dams with Hereford vs Angus dams (BGB), of Brahman-sired with Sahiwal-sired dams (BGC) and of Pinzgauersired dams with $\mathrm{HA}$ and $\mathrm{AH}$ crossbred dams (BGD). Other breed groups of dam contrasts and their interactions with the location effect were computed but are not reported here. These included comparisons of BA with $\mathrm{BH}$, SA with SH and PA with PH crossbred dams.

\section{Results and Discussion}

Summaries of the analyses of variance are given in Tables 2 and 3. Effects of LBG, year and sex (except for pregnancy rate) were important sources of variation of all traits, with the exception of survival rate, in which neither LBG nor year was significant. The interaction of LBG and year affected $(P<.05)$ all traits except rate of unassisted calving. The linear and quadratic effects of age of dam affected most traits. The linear and quadratic effects of age of calf affected $(P<.05)$ preweaning average daily gain and weaning weight.

Repeatabilities were found to be $.177 \pm .018$ for pregnancy rate, $.089 \pm .018$ for calf survival rate, $.046 \pm .016$ for rate of unassisted calving and $.069 \pm .018$ for age of calf at weaning. Generally larger repeatabilities were observed for the weight traits of birth weight $(.175 \pm .020)$, preweaning average daily gain $(.420 \pm .022)$ and weaning weight $(.408 \pm$ $.022)$.

Year Effects. The variability represented by the effect of years in analyses of beef cattle data often represents more than simply the effects of climatic and nutritional differences among years. In many studies, year effects include the influences of different sires and of a changing cow herd. In this study, year effects included an even greater combination of influences. They included true year differences and sire breed of calf differences. The partial confounding of year effects with breed of sire of calf was due to the practice of mating heifers to Red Poll sires, with succeeding calves being sired by Simmental sires. Year effects also were confounded with age of dam because all breeding females were born in 1975 and 1976. It is appropriate to remove the effects of these important sources of variation to permit study of the effects of breed group, location and their interaction on the traits evaluated.

Reproductive Traits. Least squares estimates for pregnancy rate and calf age at weaning are shown in Table 4. Linear functions of the LBG means, which permit the 


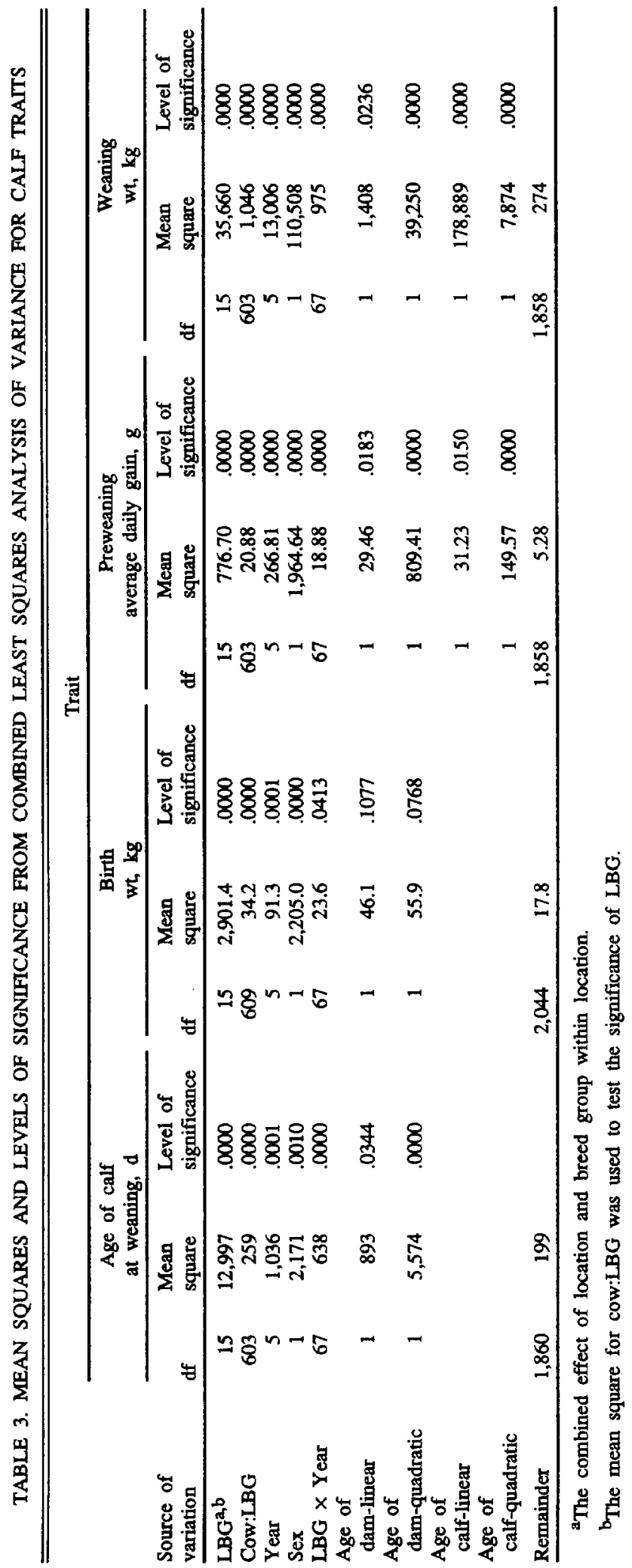


evaluation of selected breed group of dam comparisons, the location effects and the interaction between them are shown in Table 5. The latter is of primary interest. The pregnancy rate in Nebraska was 9 percentage units higher than in Florida. This can be attributed largely to the better nutritional environment provided in Nebraska and perhaps to the temperate climate. The pregnancy rates of Zebu crossbred dams (BA, BH, SA and SH) surpassed those of the $\mathrm{Bt} \times \mathrm{Bt}$ crossbred dams (AH, HA, PA, PH) by 3.8 percentage units. The interaction of location with this breed group comparison approached significance $(P$ $=.061$ ); the advantage of the Zebu crossbred dams for pregnancy rate was much larger in Florida (5.8\% units) than it was in Nebraska (1.8\% units). Bailey et al. (1988) also reported a slightly higher pregnancy rate of Brahman crossbred dams than of Bos taurus crossbred dams in a temperate environment (Nevada). Both the Zebu crossbred dams and the Bos taurus crossbred dams showed substantial increases in pregnancy rate under the more favorable, temperate conditions in Nebraska. The pregnancy rate of the Sahiwal crossbred dams surpassed that of Brahman crossbred dams, but this advantage was not significant.
Calves were weaned $20.8 \mathrm{~d}$ younger in Nebraska, and calves from Zebu crossbred dams were $1.1 \mathrm{~d}$ older at weaning $(P=.108)$ than calves from Bos taurus crossbred dams (Table 5). The interaction of location with this breed group of dam comparison, however, was highly significant and its sign indicates again a greater advantage of the Zebu crossbred dams in Florida. Calves from Sahiwal crossbred dams were nearly $3 \mathrm{~d}$ older $(P<.01)$ than calves from Brahman crossbred dams.

Calving Difficulty. The rate of unassisted calving was $4.6 \%$ units higher $(P<.001)$ in Florida than in Nebraska (Table 5). The increased assistance required in Nebraska likely was influenced by the higher birth weights at that location $(P<.001$, Tables 6 and 7). Because of concem that the location effect may have been biased by the fact that there were more Simmental-sired calves born in Nebraska, separate analyses were run for each sire breed. There were no differences $(P>$ .30 ) in the normal calving rate of Simmentalsired calves between the two locations, but all dams were at least 3 yr of age at calving. Red Poll-sired calves bom in Florida had a $30.0 \%$ higher normal calving rate $(P<.001)$ than those bom in Nebraska. This large location

TABLE 4. LEAST SQUARES ESTIMATES (LSM) AND SE FOR PREGNANCY RATE, AGE OF CALF AT WEANING, UNASSISTED CALVING RATE AND SURVIVAL RATE BY LOCATION-BREED GROUP

\begin{tabular}{|c|c|c|c|c|c|c|c|c|}
\hline \multirow{3}{*}{$\begin{array}{l}\text { Location-breed } \\
\text { group }^{\mathrm{a}}\end{array}$} & \multicolumn{8}{|c|}{ Trait } \\
\hline & \multicolumn{2}{|c|}{$\begin{array}{c}\text { Pregnancy } \\
\text { rate, } \%\end{array}$} & \multicolumn{2}{|c|}{$\begin{array}{l}\text { Age of calf } \\
\text { at weaning, d }\end{array}$} & \multicolumn{2}{|c|}{$\begin{array}{c}\text { Unassisted } \\
\text { calving } \\
\text { rate, } \%\end{array}$} & \multicolumn{2}{|c|}{$\begin{array}{l}\text { Survival } \\
\text { rate, } \%\end{array}$} \\
\hline & LSM & SE & LSM & SE & LSM & SE & LSM & SE \\
\hline \multicolumn{9}{|l|}{ Florida } \\
\hline Hereford-Angus (HA) & .750 & .033 & 217.0 & 2.0 & .967 & .027 & .965 & .031 \\
\hline Angus-Hereford (AH) & .920 & .038 & 212.1 & 2.0 & .948 & .028 & .988 & .033 \\
\hline Pinzgauer-Angus (PA) & .811 & .031 & 213.8 & 1.8 & .925 & .026 & .940 & .029 \\
\hline Pinzgauer-Hereford (PH) & .790 & .040 & 211.0 & 2.2 & .904 & .031 & .949 & .036 \\
\hline Brahman-Angus (BA) & .852 & .031 & 216.3 & 1.7 & .991 & .025 & .986 & .027 \\
\hline Brahman-Hereford (BH) & .866 & .036 & 213.7 & 2.0 & .972 & .027 & .965 & .032 \\
\hline Sahiwal-Angus (SA) & .903 & .032 & 218.4 & 1.7 & .981 & .025 & .972 & .028 \\
\hline Sahiwal-Hereford (SH) & .881 & .034 & 218.7 & 1.9 & .978 & .026 & .977 & .030 \\
\hline \multicolumn{9}{|l|}{ Nebraska } \\
\hline Hereford-Angus & .943 & .019 & 193.7 & 1.3 & .815 & .015 & .913 & .016 \\
\hline Angus-Hereford & .905 & .029 & 195.7 & 1.7 & .889 & .022 & .950 & .025 \\
\hline Pinzgauer-Angus & .924 & .020 & 194.6 & 1.3 & .872 & .025 & .924 & .017 \\
\hline Pinzgauer-Hereford & .940 & .040 & 195.6 & 1.5 & .820 & .019 & .924 & .021 \\
\hline Brahman-Angus & .950 & .020 & 193.4 & 1.3 & .987 & .015 & .891 & .021 \\
\hline Brahman-Hereford & .928 & .024 & 192.0 & 1.5 & .981 & .018 & .930 & .017 \\
\hline Sahiwal-Angus & .959 & .023 & 194.4 & 1.5 & .980 & .017 & .905 & .019 \\
\hline Sahiwal-Hereford & .947 & .030 & 195.2 & 1.7 & .954 & .022 & .942 & .026 \\
\hline
\end{tabular}

"Sire breed listed first. 
difference likely is influenced by the age of calving difference (nearly 1 yr younger in Nebraska) and the 6.36-kg heavier birth weight in Nebraska. A large advantage of 8.5 percentage units $(P<.001)$ was observed in the Zebu crossbred dams over the Bos taurus crossbred dams. McElhenney et al. (1985) also reported less calving difficulty for $\mathrm{BA}$ and $\mathrm{BH}$ crossbred dams than for $\mathrm{AH}$ and HA crossbred dams. Morrison et al. (1989) observed that Brahman-sired crossbred cows had less calving difficulty than Continental European-sired crossbred cows in Louisiana. The advantage of Zebu crossbred dams for this trait likely was related to the combination of a larger pelvic area and a lowered calf birth weight (Tables 6 and 7). McElhenney et al. (1985) found that Brahman females had pelvic height measurements at first calving that were higher than those of the Bos taurus females in their study; however, they were also older than the Bos taurus females. The interaction of location with this breed group contrast also was important $(P<.001)$ and indicated a greater advantage of the Zebu crossbred dams in Nebraska, where more calving difficulty was observed.

Calf Survival Rate. Calves bom in Florida had a higher survival rate $(P<.001)$ than those born in Nebraska (Tables 4 and 5). The advantage of 4.6 percentage units for the Florida-born calves was the same as that observed for rate of unassisted calving in Florida. The separate analyses of calf survival $x$ breed of sire indicated an advantage in calf survival rate for the Florida location for both Red Poll- and Simmental-sired calves. The advantage for the Florida location, however, was larger (6.4 vs $2.9 \%$ ) for the Red Poll-sired calves from the younger cows. The reduced incidence of calving difficulty of the Zebu crossbred dams was not reflected in a higher survival rate of their calves. Bailey et al. (1988) also failed to find an advantage of BA and $\mathrm{BH}$ dams over $\mathrm{AH}$ and $\mathrm{HA}$ crossbred dams for calf survival rate. On the other hand, McElhenney et al. (1985) observed an advantage of $\mathrm{BA}$ and $\mathrm{BH}$ over $\mathrm{AH}$ and $\mathrm{HA}$ crossbred dams for calf survival.

TABLE 5. LINEAR CONTRASTS (LC) AND SE OF LOCATION, BREED-GROUP AND LOCATION $\times$ BREED-GROUP INTERACTION EFFECTS FOR PREGNANCY RATE, UNASSISTED CALVING RATE AND SURVIVAL RATE

\begin{tabular}{|c|c|c|c|c|c|c|c|c|c|c|c|c|}
\hline \multirow[b]{3}{*}{$\begin{array}{l}\text { Description of } \\
\text { contrast }\end{array}$} & \multicolumn{12}{|c|}{ Trait } \\
\hline & \multicolumn{3}{|c|}{ Pregnancy rate, \% } & \multicolumn{3}{|c|}{$\begin{array}{c}\text { Age of calf at } \\
\text { weaning, } d\end{array}$} & \multicolumn{3}{|c|}{ Unassisted calving, $\%$} & \multicolumn{3}{|c|}{ Calf survival rate, \% } \\
\hline & LC & SE & $\begin{array}{l}\text { Level } \\
\text { of } \\
\text { signifi- } \\
\text { cance }\end{array}$ & $\mathrm{LC}$ & SE & $\begin{array}{l}\text { Level } \\
\text { of } \\
\text { signifi- } \\
\text { cance }\end{array}$ & LC & SE & $\begin{array}{l}\text { Level } \\
\text { of } \\
\text { signifi- } \\
\text { cance }\end{array}$ & $\mathbf{L C}$ & SE & $\begin{array}{l}\text { Level } \\
\text { of } \\
\text { signifi- } \\
\text { cance }\end{array}$ \\
\hline Nebraska-Florida (L) & .090 & .011 & .000 & -20.8 & .7 & .000 & -.046 & .011 & .000 & -.046 & .011 & .000 \\
\hline $\begin{array}{l}\text { Brahrnan and Sahiwal } \\
\text { crossbred cows }- \text { Bos } \\
\text { taurus } \times \text { Bos taurus } \\
\text { crossbred cows (BGA) }\end{array}$ & .038 & .011 & .000 & 1.1 & .7 & .108 & .085 & .010 & .000 & .010 & .011 & .381 \\
\hline $\mathrm{L} \times \mathrm{BGA}$ & -.039 & .021 & .061 & -4.5 & 1.3 & .001 & .082 & .021 & .000 & -.010 & .022 & .643 \\
\hline $\begin{array}{l}\text { Crossbred cows from } \\
\text { Angus dams - crossbred } \\
\text { cows from Hereford } \\
\text { dams (BGB) }\end{array}$ & $\mathrm{d}^{-.011}$ & .011 & .321 & 1.0 & .7 & .141 & .009 & .010 & .396 & -.002 & .011 & .843 \\
\hline $\mathrm{L} \times \mathrm{BGB}$ & .049 & .021 & .023 & -3.1 & 1.3 & .018 & -.013 & .021 & .537 & .004 & .022 & .868 \\
\hline $\begin{array}{l}\text { Brahman crossbred } \\
\text { cows - Sahiwal } \\
\text { crossbred cows (BGC) }\end{array}$ & -.023 & .015 & .117 & -2.8 & .9 & .002 & .009 & .014 & .516 & -.006 & .015 & .677 \\
\hline $\mathrm{L} \times \mathrm{BGC}$ & .019 & .03 & .519 & 1.4 & 1.8 & .427 & .015 & .028 & .607 & -.014 & .030 & .651 \\
\hline $\begin{array}{l}\text { Pinzgauer crossbred } \\
\text { cows - Hereford } x \\
\text { Angus and reciprocal } \\
\text { crossbred cows (BGD) }\end{array}$ & -.013 & .015 & .381 & -.9 & 1.0 & .370 & -.024 & .015 & .112 & -.028 & .016 & .084 \\
\hline $\mathrm{L} \times \mathbf{B G D}$ & .042 & .031 & .170 & 2.5 & 1.9 & .188 & .036 & .030 & .230 & .008 & .032 & .799 \\
\hline
\end{tabular}


Birth Weight. Calves born in Florida were $8.0 \mathrm{~kg}$ lighter than those born in Nebraska (Tables 6 and 7). When the sire breed of calf was analyzed separately, Red Poll- and Simmental-sired calves were 6.4 and $7.4 \mathrm{~kg}$ heavier at birth in Nebraska. This result is consistent with those of Butts et al. (1971) and Burns et al. (1979), who reported lower birth weights in Florida than in Montana. In their studies with Hereford cattle, the reduction was greater in Florida for the introduced line than for the adapted line. A similar result was observed in this study in that the reduction in birth weight in Florida relative to Nebraska was $6.9 \mathrm{~kg}$ in calves from $\mathrm{Bi} \times \mathrm{Bt}$ crossbred dams and $9.0 \mathrm{~kg}$ in calves from $\mathrm{Bt} \times \mathrm{Bt}$ crossbred dams. This difference is reflected in the highly significant interaction effect for location with this breed group comparison (Table 7). Calves from Zebu crossbred dams were $3.4 \mathrm{~kg}$ lighter at birth than calves from Bos taurus crossbred dams. Reductions in birth weight of calves from BA and BH crossbred dams compared with birth weight calves from $\mathrm{HA}$ and $\mathrm{AH}$ crossbred dams also were observed by McElhenney et al. (1985) and Bailey et al. (1988). Morrison et al. (1989) reported that birth weights of calves from Brahman crossbred cows were lighter than those from comparably sized Chianina and Maine-Anjou-sired crossbred cows. These results also are in accord with those of Wyatt and Franke (1986), who reported a Brahman additive maternal breed effect of $-6.1 \mathrm{~kg}$ on birth weight. Calves from Brahman crossbred dams were $3.4 \mathrm{~kg}$ heavier at birth than those from Sahiwal crossbred dams. The interaction of this breed group contrast, in which both groups were half Zebu, with location was not significant. Pinzgauer crossbred dams produced calves that were $3.6 \mathrm{~kg}$ heavier at birth than those from HA and $\mathrm{AH}$ crossbred dams. This breed group comparison, in which all females were Bos taurus crossbreds, also failed to produce a significant interaction with location.

Preweaning Average Daily Gain and Weaning Weight. The better nutritional environment combined with the effects of the temperate environment of the Nebraska location clearly is evidenced by the higher $(P<.001)$ preweaning average daily gain and weaning weights in Nebraska (Tables 6 and 7). These highly significant differences in growth traits were also observed when Simmental-sired calves were analyzed separately. The advantage of the Zebu crossbred dams over Bos taurus crossbred dams, however, was greater

TABLE 6. LEAST SQUARES ESTIMATES (LSM) AND SE FOR BIRTH WEIGHT, WEANING WEIGHT AND PREWEANING AVERAGE DAILY GAIN BY LOCATION-BREED GROUP

\begin{tabular}{|c|c|c|c|c|c|c|}
\hline \multicolumn{7}{|c|}{ Trait } \\
\hline \multirow[b]{2}{*}{ Location-breed group $^{a}$} & \multicolumn{2}{|c|}{ Birth wt, kg } & \multicolumn{2}{|c|}{ Weaning wt, kg } & \multicolumn{2}{|c|}{$\begin{array}{c}\text { Preweaning average } \\
\text { daily gain, } \mathrm{kg}\end{array}$} \\
\hline & LSM & SE & LSM & SE & LSM & SE \\
\hline \multicolumn{7}{|l|}{ Florida } \\
\hline Hereford-Angus (HA) & 27.7 & .7 & 194.1 & 3.8 & .81 & .02 \\
\hline Angus-Hereford (AH) & 26.9 & .7 & 202.3 & 4.1 & .85 & .02 \\
\hline Pinzgauer-Angus (PA) & 31.3 & .6 & 212.5 & 3.6 & .88 & .02 \\
\hline Pinzgauer-Hereford (PH) & 31.7 & .7 & 217.0 & 4.2 & .90 & .02 \\
\hline Brahman-Angus (BA) & 29.1 & .6 & 250.6 & 3.5 & 1.06 & .02 \\
\hline Brahman-Hereford (BH) & 28.8 & .7 & 251.5 & 4.0 & 1.07 & .02 \\
\hline Sahiwal-Angus (SA) & 24.9 & .6 & 235.9 & 3.6 & 1.01 & .02 \\
\hline Sahiwal-Hereford (SH) & 25.4 & .7 & 238.3 & 3.9 & 1.02 & .02 \\
\hline \multicolumn{7}{|l|}{ Nebraska } \\
\hline Hereford-Angus & 36.4 & .5 & 222.3 & 2.8 & .90 & .01 \\
\hline Angus-Hereford & 37.4 & .6 & 230.1 & 3.6 & .93 & .02 \\
\hline Pinzgauer-Angus & 39.1 & .5 & 241.8 & 2.9 & .98 & .01 \\
\hline Pinzgauer-Hereford & 40.7 & .5 & 244.8 & 3.2 & .99 & .02 \\
\hline Brahman-Angus & 34.9 & .5 & 254.0 & 2.9 & 1.06 & .01 \\
\hline Brahman-Hereford & 36.0 & .5 & 253.7 & 3.3 & 1.06 & .02 \\
\hline Sahiwal-Angus & 31.5 & .5 & 237.7 & 3.1 & .99 & .01 \\
\hline Sahiwal-Hereford & 33.5 & 6 & 242.6 & 3.7 & 1.01 & .02 \\
\hline
\end{tabular}

${ }^{a}$ Sire breed listed first. 
than that of location difference, over three times as large for preweaning average daily gain (Table 7). McElhenney et al. (1985) also reported that preweaning average daily gains and weaning weights of calves from BA and $\mathrm{BH}$ dams were greater than those of $\mathrm{HA}$ and AH crossbred dams in Texas. Bailey et al. (1988), however, failed to show such an advantage in Nevada. The results of the comprehensive study of Wyatt and Franke (1986), using data from the southern region, support those of this study in that the breed additive maternal effect for the Brahman breed was found to be superior to that of the Angus and the Hereford breeds for both preweaning average daily gain and weaning weight. In addition, Wyatt and Franke found matemal heterosis effects of Brahman $\times$ Hereford and Brahman $x$ Angus crossbred dams to be substantially higher than those of Hereford $x$ Angus crossbred dams for preweaning average daily gain and weaning weight.

Milk yield likely is a major factor influencing the superiority of the Zebu crossbred dams. Cundiff et al. (1981) reported that 12-h milk yields of 3-yr-old Brahman and Sahiwal crossbred dams in Nebraska were 3.8 and 3.5 $\mathrm{kg}$, respectively, vs yields of 3.3 and $2.4 \mathrm{~kg}$ for
Pinzgauer crossbred and Hereford $\times$ Angus plus reciprocal crossbred combined, respectively. In contrast, Daley et al. (1987) found that $\mathrm{BA}$ and $\mathrm{BH}$ were inferior to $\mathrm{AH}$ in daily milk yield early in lactation (60 d) but were more persistent and by $150 \mathrm{~d}$ equaled or surpassed the milk yield of the AH dams.

Three other breed group of dam linear contrasts are shown in Table 7. Crossbred cows from Hereford dams produced calves that gained faster $(P<.001)$ and weaned at heavier weights $(P<.001)$ than crossbred cows from Angus dams. Brahman-sired crossbred dams produced calves that gained faster $(P<.001)$ and had heavier weaning weights $(P<.001)$ than calves from Sahiwal-sired crossbred dams. A comparable advantage was observed for Pinzgauer-sired dams over $\mathrm{HA}$ and $\mathrm{AH}$ dams for these traits. None of the interactions of location with these breed groups of dams were important $(P>.23)$ for either preweaning average daily gain or for weaning weight.

The interaction of the $\mathrm{Bi} \times \mathrm{Bt}$ dam vs $\mathrm{Bt} \times$ Bt dam comparison with location was highly significant $(P<.001)$ for both preweaning average daily gain and weaning weight (Table 7). This interaction was due to a much greater advantage in Florida than in Nebraska for

TABLE 7. LINEAR CONTRASTS (LC) AND SE OF LOCATION, BREED-GROUP AND LOCATION $x$ BREED-GROUP INTERACTION EFFECTS FOR BIRTH WEIGHT, WEANING WEIGHT AND PREWEANING AVERAGE DAILY GAIN

\begin{tabular}{|c|c|c|c|c|c|c|c|c|c|}
\hline \multirow[b]{3}{*}{ Description of contrast } & \multicolumn{9}{|c|}{ Trait } \\
\hline & \multicolumn{3}{|c|}{ Birth wt, $\mathrm{kg}$} & \multicolumn{3}{|c|}{ Weaning wt, $\mathbf{k g}$} & \multicolumn{3}{|c|}{$\begin{array}{l}\text { Preweaning averagey } \\
\text { daily gain, } \mathbf{g}\end{array}$} \\
\hline & LC & SE & $\begin{array}{l}\text { Level of } \\
\text { significance }\end{array}$ & LC & SE & $\begin{array}{l}\text { Level of } \\
\text { significance }\end{array}$ & $\mathbf{L C}$ & SE & $\begin{array}{l}\text { Level of } \\
\text { significance }\end{array}$ \\
\hline Nebraska-Florida (L) & 8.0 & .2 & .000 & 15.6 & 1.0 & .000 & 40 & 5 & .000 \\
\hline $\begin{array}{l}\text { Brahman and Sahiwal } \\
\text { crossbred cows }- \text { Bos } \\
\text { taurus } \times \text { Bos taurus } \\
\text { crossbred cows (BGA) }\end{array}$ & -3.4 & .2 & .000 & 24.9 & .9 & .000 & 131 & 3 & .000 \\
\hline $\mathrm{L} \times \mathrm{BGA}$ & -2.1 & .4 & .000 & -25.3 & 1.6 & .000 & -99 & 7 & .000 \\
\hline $\begin{array}{l}\text { Crossbred cows Angus } \\
\text { dams - crossbred cows } \\
\text { from Hereford dams (BGB) }\end{array}$ & -.7 & .2 & .001 & -3.9 & .8 & .000 & -16 & 3 & .000 \\
\hline $\mathrm{L} \times \mathrm{BGB}$ & -1.4 & .4 & .000 & .1 & 1.6 & .924 & 5 & 7 & .441 \\
\hline $\begin{array}{l}\text { Brahman crossbred } \\
\text { cows - Sahiwal crassbred } \\
\text { cows (BGC) }\end{array}$ & 3.4 & .3 & .000 & 13.8 & 1.1 & .000 & 54 & 5 & .000 \\
\hline $\mathrm{L} \times \mathrm{BGC}$ & .8 & .5 & .115 & .3 & 2.1 & .907 & 6 & 9 & .535 \\
\hline $\begin{array}{l}\text { Pinzgauer crossbred } \\
\text { cows - Hereford } \times \text { Angus } \\
\text { and reciprocal crossbred } \\
\text { cows (BGD) }\end{array}$ & 3.6 & .3 & .000 & 16.8 & 1.1 & .000 & 64 & 5 & .000 \\
\hline $\mathbf{L} \times \mathbf{B G D}$ & -1.1 & .6 & .040 & .6 & 2.3 & .805 & 12 & 10 & .236 \\
\hline
\end{tabular}


calves from Zebu crossbred dams for both preweaning average daily gain and weaning weight. The comparison of the performance of the Pinzgauer- vs the Sahiwal-sired crossbred dams is of particular interest because the calves from Sahiwal-sired crossbred dams gained faster and were heavier at weaning $(P<$ .01) than those of Pinzgauer-sired dams in Florida but gained at similar rates preweaning and were slightly lighter at weaning than those from Pinzgauer-sired dams in Nebraska. Brahman-sired dams, however, produced the fastest-gaining and heaviest calves at weaning at both locations. Brahman- and Sahiwal-sired dams produced calves that weaned at essentially equal weights at both locations, whereas the Bos taurus crossbreds weaned heavier calves in Nebraska than in Florida. This result suggests a wider range of adaptability for Zebu crossbred dams than for Bos taurus crossbred dams. Peters and Slen (1967) reported superiority of Brahman crossbred dams in Canada.

Butts et al. (1971) found a similar type of interaction but also indicated a change in ranking across locations, because weaning weight tended to be higher for calves evaluated under the environment in which their parent line originated. Burns et al. (1979) evaluated Phase 2 of this study that compared two lines originating from Montana (Line 1) Herefords, one selected in Florida and the other in Montana. Calves at each location sired by bulls selected at that location surpassed those of calves sired by bulls selected in the other location for preweaning average daily gain and weaning weight. The magnitude of this advantage of the "local" over the introduced cattle was similar to that of the initial study. Genotype of environment (level of nutrition) interactions were evident in the study conducted by Peacock et al. (1969). Changes in rank of breeds in different environments also were reported by Baker et al. (1981), who evaluated 11 crossbred groups in two extreme environments in New Zealand and demonstrated that the Simmental crosses ranked second under good environmental conditions but ranked only seventh when they were evaluated under a harsher environment.

The kilograms of calf weaned per cow exposed to breeding can be calculated from the data presented in Tables 4 and 6 by multiplying together the pregnancy rates, the calf survival rates and the calf weaning weights. The kilograms of calf weaned per cow exposed to breeding were 160.5 and $208.2 \mathrm{~kg}$, respectively, for $\mathrm{Bt} \times \mathrm{Bt}$ crossbred and $\mathrm{Bi} \times \mathrm{Bt}$ crossbred cows in Florida and were 200.2 and $215.8 \mathrm{~kg}$ for the same breed groups in Nebraska. The same pattern was seen for this measure of productivity as had been seen for weaning weight. Whereas the Zebu crossbred cows were superior at both locations, the advantage in Florida was three times that in Nebraska.

\section{Impllcations}

The advantage of Bos indicus crossbred cows in the southeastern U.S. was clearly documented. Weaning weights of calves from Bos indicus $\times$ Bos taurus crossbred cows also equaled or exceeded those from Bos taurus crossbred cows under temperate conditions. The Zebu crossbred cows had lower calf birth weights and calved more easily than Bos taurus crossbred cows. These advantages, however, must be weighed against the increased incidence of dystocia when Brahman sires are mated to Bos taurus females, the price discount for feeder-stocker calves with distinctive Zebu characteristics and the negative effect that Zebu breeds have on beef tenderness. The successful implementation of a sexed semen program, which would allow the production of only heifers from Bos indicus $\times$ Bos taurus $F_{1}$ crosses, would reduce the dystocia problem and eliminate the production of the less desired male calves. The large location effects and breed group $\times$ location interactions found for the Zebu crossbred vs Bos taurus crossbred dams also have implications for sire and breed evaluations.

\section{Literature Cited}

Bailey, C. M., D. R. Hanks, W. D. Foote and Y. O. Koh. 1988. Maternal characteristics of young dams representing Bos taurus and Bos indicus $\times$ Bos taurus breed types. J. Anim. Sci. 66:1144.

Baker, R. L., A. H. Carter and J. P. Muller. 1981. Performance of crossbred cows in the Ruakura beef breed evaluation trail, Proc. N.Z. Soc. Anim. Prod. 41: 254.

Burns, W. C., M. Koger, W. T. Butts, O. F. Pahnish and R. L. Blackwell. 1979. Genotype by environment interaction in Hereford cattle: $I$. Birth and weaning traits. J. Anim. Sci. 49:403.

Butts, W. T., M. Koger, O. F. Pahnish, W. C. Burns and E. J. Warnick. 1971. Performance of two lines of Hereford cattle in two environments. J. Anim. Sci. 33:923.

Cundiff, L. V., K. E. Gregory and R. M. Koch. 1981. Germ Plasm Evaluation Program. Prog. Rep. No. 9. USDA, ARS, Washington, DC. 
Daley, D. R., A. McCuskey and C. M. Bailey. 1987. Composition and yield of milk from beef-type Bos taurus and Bos indicus $\times$ Bos taurus dams. J. Anim. Sci. 64:373.

Gregory, K. E. and L. V. Cundiff. 1980. Crossbreeding beef cattle: evaluation of systems, J. Anim. Sci. 51:1224.

Gregory, K. E., G. M. Smith L. V. Cundiff, R. M. Koch and D. B. Laster. 1979. Characterization of biological types of cattle-Cycle III. 1 . Birth and weaning traits. $J$. Anim. Sci. 48:271.

Harvey, W. R. 1987. User's Guide for Mixed Model LeastSquares and Maximum Likelihood Computer Program. The Ohio State Univ., Columbus (Mimeo).

Koger, M., W. C. Burns, O. F. Pahnish and W. T. Butts 1979. Genotype by environment interactions in Hereford cattle: I. Reproductive traits. J. Anim. Sci. 49: 396.

Koger, M., F. M. Peacock, W. G. Kirk and J. R. Crockett. 1975. Heterosis effects on weaning performance of Brahman-Shorthorn calves. J. Anim. Sci. 40:826.

McElhenney, W. H., C. R. Long, J. F. Baker and T. C Cartwright. 1985. Production characters of firstgeneration cows of a five-breed diallel: Reproduction of young cows and preweaning performance of inter se calves. J. Anim. Sci. 61:55.

Morrison, D. G., P. E. Humes and K. L. Koonce. 1989. Comparisons of Brahman and continental European crossbred cows for calving ease in a subtropical environment. J. Anim. Sci. 67:1722.

Pahnish, O. F., M. Koger, J. J. Urick, W. C. Burns, W. T. Butts and G. V. Richardson. 1983. Genotype by environment interaction in Hereford cattle. III. Postweaning traits of heifers. J. Anim. Sci. 56:1039.

Pahnish, O. F. J. J. Urick, W. C. Bums, W. T. Butts, M. Koger and R. L. Blackwell. 1985. Genotype $\times$ environment interaction in Hereford cattle: IV. Postweaning traits of bulls. J. Anim. Sci. 61:1146.

Peacock, F. M., W. G. Kirk, E. M. Hodges, W. L. Reynolds and M. Koger. 1969. Genetic and environmental influences on weaning weight and slaughter grade of Brahman, Shorthorn and Brahman-Shorthorn crossbred calves. Florida Agric. Exp. Sta. Bull. 624.

Peacock, F. M., M. Koger, T. A. Olson and J. R. Crockett. 1981. Additive genetic and heterosis effects in crosses among cattle breeds of British, European and Zebu origin. J. Anim. Sci. 52:1007.

Peters, H. F. and S. B. Slen. 1967. Brahman-British beef cattle crosses in Canada. I. Weaned calf production under range conditions. Can. J. Anim. Sci. 47:145.

Wyatt, W. E. and D. E. Franke. 1986. Estimation of direct and maternal additive and heterotic effects for preweaning growth traits in cattle breeds represented in the southern region. Southern Coop. Series Bull. 310, Louisiana State Univ., Baton Rouge. 